\section{STRATEGIC VECTORS OF FOOD PRODUCTION DEVELOPMENT IN SERBIA IN TERMS OF THE GLOBAL CRISIS}

\author{
JEL Classifications: L66, O13, Q17, Q18, Q27
}

\author{
RuZica Milovanovic, Ph.D. \\ Faculty of Economics \\ University of Kragujevac, Serbia
}

Key words: Food production, economic crisis, strategy, technological development, quality, ecological criterion.

\begin{abstract}
The world economic crisis was a major factor that caused industrial production and trade over the globe decrease. It closed millions of working places and effected fear of political instability to spread even over the states that have been considered as stable. Economies all over the world face with wide range recessions, that will lead to the 3\% to $7 \%$ GNP drop with respect to the last decade increasing trend. In such uncertainty conditions, where authorities are not sure about crisis development and duration, banner task is imposed: uncertainty must be passed. In Serbian economy, good model for crisis overcoming is agriculture strategic development and especially within it, the safe food production. One of guidelines of Serbian agriculture development is modernization and change of production structure towards stronger market orientation and improvement of alimentary industry total efficiency. Increased productively technological restructuring achieving increased efficiency, as well as greater competitiveness at domestic and foreign markets should be based on economical, ecological and energy criterions. Also, applied scientific research papers should allow significant increase of size and competitiveness of Serbian agriculture production
\end{abstract}

\section{Introduction}

Food and liquor sector of agriculture production is one very profitable part of EU economy. Also, it is the most profitable economy sector in Serbian economy and its part in Serbian GNP is increasing (The Serbian statistic institute). According to the FAO data, in period 2000-2004, the mean value of world food trading was $984 * 10^{9}$ USD (import about $504.8 * 10^{9}$ USD and export about $479.3 * 10^{9}$ USD). This shows the value and size of international food products trading, though risk that this kind of trade brings (Radovanovic, 2003).

In spite of achieved qualities, EU sector in agricultural and alimentary realm faces with strong competition. Beside the traditional competitors from North America and from Japan, some new economies in development like China, India, Brazil and Australia are arising. Consequence is the drop of EU presence at the global markets of food and liquor in last decade from $24 \%$ to $23 \%$ (Radovanovic, 2007). Exterior trade processes in agricultural-alimentary products exchange in Serbia were conducted, before transitional changes, in conditions of disordered macroeconomics balance. Serbian export value of agricultural and alimentary products is one billion USD in 2006 and 1.5 billion USD in 2007 (Botos, 2003). Almost $60 \%$ of Serbian export structure is raw materials or products of the lowest fabrication phase (semi products), while at the developed countries that percentage is below 2\%. Prosperous economies in transition (Czech Republic, Hungary, Poland, Romania and Lithuania) have natural resources export participating in overall export with $37 \%$ to $48 \%$. Some analysis shows that about $28 \%$ of all Serbian companies export their products to foreign markets, average $10 \%$ of its entire production (Stojanovic, 2006).

Entering the reform processes, achieved macroeconomic stability, upgrading system regulations and privatization conditioned proper conditions for production; taken policies provided support for developing export possibilities of agriculture. According to the Serbian Statistic Institute, industrial production increased for $3 \%$ in 2009 . Increase is recorded in 17 fields providing $73 \%$ of overall production volume. Alimentary products production delivered the biggest impact to production growth. The fact is that the domestic market is limiting factor for rational usage of significant agro economics, production and human resources. For that reason, the export orientation is precondition for total efficiency increasing of agro industrial production and its faster fitting into world market and into EU integration processes.

\section{Strategic food production}

European agricultural and alimentary sector is one of the most important industrial branches for EU economy. After the United States, the second best result in international food products trade accomplished by countries from Europe, with mean value of $476 * 10^{9}$ USD per year (Radovanovic, 2007).

Serbia also realized significant extern trading food traffic. In the last five years, the accomplished mean value of food trading was $1.1 * 10^{9}$ USD per year, where import value was $636^{*} 10^{6}$ USD worth and value of export was $474 * 10^{6}$ USD. Serbian alimentary industry export growth signals that processes of improvement of production efficiency and size have started. Concern about production of alimentary products finds its roots in production phases prior to industrial processing and reprocessing, i.e. in the prime agricultural production. It is livestock breeding which is governed by consumers and markets need, especially in the industrialized countries. In such integral production chain, breeders and producers in animal husbandry are connected with feeding stuffs factories, butcheries and retail trades to guarantee production of proper quantity and high quality. Such business conditions affect on orientation change of prime producers: from quantity to quality of production. This means that they change production approach from exclusively managerial or economical toward higher approaches, like social or environmental ones. Within industrial production realm, producers have to understand better demands of particular 
markets; e.g. that products with different components are made to different countries/markets according to specific behavior of resident consumers. Concerning the fact that the cattle breading is the most intense agriculture branch and very important bond in the EU association process, the question of its position in Serbia can be created. Sector of animal husbandry is burdened with many problems caused by previously implemented for decades improper agrarian policy; very long period of isolation caused backing in monitoring and involving modern science trends in production and trade processes.

Animal husbandry makes the most intense branch of agricultural production and has great meaning as for producers, so as for processors and consumers. Animal husbandry products are high quality food products, because they have significant nutritiousness and excellent biological properties. As well, these products are big export item as they have strategic character. Because of that, production intensification in cattle breeding and providing through this growth and higher participation of this industry in the overall agricultural production is the main demand and need.

\section{Food production updating}

Revitalization as well as updating of high capacity drive unit seems as preferred vector of technological development in this sector; it will enable production update based on the most automated processes. Also, labour cost in the product price could be decreased. With maximum standardization of production process and product quality, proper competitiveness at the global market is achievable. By founding the new ones, or by updating existing ones, companies for animal husbandry, with implementation of the contemporary technological sustainable solutions in cattle breeding, the proper production profitable level is possible. At the same time, the tracker system of inputs (food, drugs and origin) and products (milk, eggs and meat) will be established, toward satisfying conditions for product competitiveness at the world market. At the international level, some certain demands have to be fulfilled:

keeping complete tracks of all inputs in meat production (HACCP). Hazard analysis critical control point is the systematic method for food production process analysis to detect potential damaging impacts to food products;

- ensuring export quota of meat and other alimentary raw materials;

rational resolving of privatization issue of processing plants and scientific institutions within alimentary industry, which is the industry of strategic national importance.

The tracker concept suggests constant attempt through concrete activities aimed to identify, define and clear up all problematic situations in agro alimentary products production cycles. It is necessary to remove earlier, decrease or reduce to the acceptable level all realistic potential risks in terms of product quality and safeness. Conduction of the tracker concept, as well as ensuring export quotas, is conductible only in specialized objects (farms, butcheries, manipulative and retail objects) with experts in hand (institutes for technology and control, centers for reproduction and artificial fertilization of animals).

Effectiveness of company in contemporary business conditions is determined with its capability to meet market demands. Modern business organization must rely on knowledge and constant improvement of applied knowledge level in production process, thereby improving a level of production productivity. Proficiency as the basic business resource enables to deliver more productivity of all other resources in production processes.

\section{Promotion of food export concurrence}

Crisis of the market of capital is manifesting with drastic decline of flow of goods and investment abroad. Previously, capital market was stimulating trade of international goods and services. It facilitated growth of international investment, increase of profits in industrial sectors, as well as repatriation of investors' profits. Therefore, it is realistic to anticipate that global integration and growth will be effective and sustainable only if the global market is established again. This surely is not easy task as cash flows are destabilized and circles are getting smaller and smaller.

The priority at the national economy level is speeding up competitiveness of food export. One of the general conditions for that progress is human resources (Ministry of agriculture, forestry and water management, 2004). Their capital feature is high level of competence. Experience and studies show that authority was often based only upon hierarchy, formal qualifications and years of ages, but not upon professional knowledge. It affects negatively product competitiveness while export markets demands highly quality products. Orientation should be directed toward demands of domestic and foreign market, which mean stimulation of professional education, acquirement of new knowledge and labor education. The goal of professionally education and human resources improvement is protection of required level of education, knowledge and experience.

Important condition for competitiveness improvement of export is strategic management of ecological requirements. In conditions of disturbed market values, production of products with ecological properties becomes imperative. Production and sale of ecological products provide positive contribution to decreasing of negative effects on human health, fighting against global warming by using raw and package materials that are $100 \%$ biodegradable, using less energy and alternative energy sources for producing.

Sustainable development implies development which does not wholly exhaust natural resources. Global risks in part of using biologic and genetic resources reason rapid transition to sustainable development, which has to be facilitated with motive and regulating measures. In market economy, this means that costs of healthy life environment must be built in the product cost.

\section{Conclusion}

Producers and consumers are reasonably concerned because of the challenging period of time that is approaching, 
or is already here. The global economy is slowing down more seriously than ever. Doubtfulness does not relate only to depth and duration of crisis; future of world economic order which main attribute was free flow of capital and services is also uncertain. In such conditions, Serbia should go toward meeting EU demands, to improve its content and to harden its instruments.

Particularly, Serbia has to create long term strategy for production modernization; adjust its guidelines and standards according to EU regulations; ensure safe food supply by private sector. Comparative advantages of economy should be strengthened to increase competitiveness ability. Competitiveness is achievable through promoting productions of products based on comparative advantages, technology intensive production processes. In addition, the compliance with principles of life environment preservation as well as post production way of agricultural production must be constituent part of contemporary agricultural policy.

\section{References}

Botos, M., 2003. "HACCP for Food Industry," USDA, FDA Workshop, 5, Belgrade.

CIAA, 2006. "Benchmarking Report on Food and Drink Industry Competitiveness", http://www.ciaa.be

ETP Food for Life Strategic Research Agenda, 2007-2020.

FAO, 2007, Statistical database, Rome.

Ministry of Agriculture, forestry and water management, 2004. Competetiveness of agriculture of Republic of Serbia, Study, Belgrade.

National Bank of Serbia, 2008. Statistic bulletin 2008, 12, Belgrade.

Radovanovic, R., 2003. "Certification of the HACCP concept: The experience of developed countries and our national plans," Journal Kvalitet, Vol.13, No5-6, pp.38-45.

Radovanovic, R., 2007. "Bezbednost hrane: globalni problemi kao izazov za buduce aktivnosti," Journal Kvalitet, Vol.17, No9-10, pp.20-32.

Rede, R., Petrovic, L., 1997. Technology of meat and meat science, Faculty of Technology, Novi Sad.

Stojanovic, B., 2006. "Politika zastite konkurencije i konkurentska sposobnost preduzeca," Journal Ekonomske Teme, Vol.4-5, pp.193-204. 